\title{
Potential of Parijoto (Medinilla speciosa) Fruits and Leaves in Male fertility
}

\author{
Dwi Wijayanti and Firgian Ardigurnita

\begin{abstract}
Department of Animal Science, Faculty of Agriculture, Perjuangan University of Tasikmalaya, Tasikmalaya
\end{abstract} \\ Corresponding author e-mail: wijayantidwi12@gmail.com
}

\begin{abstract}
The purpose of the study was to find out the potential of parijoto fruit and leaves qualitatively and quantitatively in male fertility. The content of fruits and parijoto were secondary compounds in the form of flavonoids, saponins, tannins, terpenoids, beta-carotene and antioxidants. Fertility is also needed in male animals. Decreased fertility in male cause a decrease in livestock productivity results in a decrease in gain from farmers. Handling of animals that occur after fertilization was usually carried out by injecting prostaglandin hormones. However, the relatively expensive price of hormones causes many farmers not to be able to buy. Another alternative that could cause a decrease in fertility was to use herbal plants, namely parijoto. The use of Parijoto plants was not certain which relevanted in fertility. Need to be tested first about phytochemical screening on parijoto leaves and fruit. The results of parijoto leaf and fruit analysis were qualitative and quantitative. The content of fruits and parijoto were secondary compounds in the form of flavonoids, saponins, tannins, terpenoids, beta-carotene and antioxidants. Parijoto fruits were founded flavonoids and saponins namely 3. $61 \% \mathrm{~b} / \mathrm{b}$ and $3.71 \% \mathrm{~b} / \mathrm{b}$. Total flavonoids and saponins in Parijoto leaves were $2.65 \% \mathrm{~b} / \mathrm{b}$ and $4.19 \% \mathrm{~b} / \mathrm{b}$. Total antioxidants, total polyphenols, tannins in parijoto leaves and fruit respectively were $36.84 \mathrm{ppm} ; 3.95 \% ; 3.52 \%$ and $20.06 \mathrm{ppm} ; 12.68 \% ; 11.70 \%$. In conclusion, the fruit and parijoto leaves have male fertility potential, and the secondary compounds of parijoto fruit were higher compared to parijoto leaves which have the potential to increase male fertility.
\end{abstract}

Key words: Antioxidants, Fertility, Flavonoids, Males, Parijoto.

Abstrak. Tujuan penelitian adalah didapatkan potensi kandungan buah dan daun parijoto secara kualitatif dan kuantitatif dalam fertilitas pejantan. Kandungan pada buah dan parijoto terdapat senyawa sekunder berupa flavonoid, saponin, tannin, terpenoid, betakaroten dan antioksidan. Kesuburan juga diperlukan pada hewan pejantan. Penurunan fertilitas pada pejantan menyebabkan penurunan produktivitas ternak sehingga berakibat penurunan pendapatkan dari peternak. Penanganan ternak yang mengalami gangguan fertilitas biasanya dilakukan dengan penyuntikan hormone prostaglandin. Namun harga hormon yang relatif mahal menyebabkan banyak peternak tidak mampu dalam membelinya. Alternatif lain yang dapat mengatasi penurunan fertilitas adalah dengan menggunakan tanaman herbal berupa parijoto. Penggunaan tanaman parijoto belum secara pasti kandungan yang berpengaruh dalam fertilitas. Sehingga perlu dilakukan pengujian terlebih dahulu mengenai skrining fitokimia pada daun dan buah parijoto. Hasil analisis kandungan buah dan daun parijoto secara kualitatif dan kuantitatif. Kandungan pada buah dan parijoto terdapat senyawa sekunder berupa flavonoid, saponin, tannin, terpenoid, betakaroten dan antioksidan. Buah parijoto ditemukan senyawa flavonoid dan saponin yaitu $3,61 \% \mathrm{~b} / \mathrm{b}$ dan $3,71 \% \mathrm{~b} / \mathrm{b}$. Total flavonoid dan saponin pada daun parijoto yaitu $2,65 \% \mathrm{~b} / \mathrm{b}$ dan $4,19 \% \mathrm{~b} / \mathrm{b}$. Total antioksidan, total polifenol, tannin pada daun dan buah parijoto berturut-turut yaitu 36,84 ppm; 3,95\%; 3,52\% dan 20,06 ppm; $12.68 \%$; $11,70 \%$. Kesimpulannya buah dan daun parijoto memiliki potensi fertilitas pejantan, dan senyawa sekunder dari buah parijoto lebih tinggi disbanding dengan daun parijoto yang meiliki potensi peningkatan fertilitas pejantan.

Kata kunci: Antioksidan, Fertilitas, Flavonoid, Jantan, Parijoto.

\section{Introduction}

Parijoto Plant (Medinilla speciosa) was a type of herbal plant that was commonly found in the village of Colo, Kudus City. The fruits of Medinilla speciosa were usually consumed by women as uterine fertilizers for those who have no offspring or who were pregnant because they could maintain pregnancy. People have believed the myth that pregnant women who consume Medinilla speciosa have beautiful or handsome children (Hanum et al., 2017). Parijoto fruit contains flavonoids, saponins, glycosides and tannins (Leliani, 2013 and Wachida, 2013). The content of saponin found 
in Parijoto has an antibacterial activity against bacteria against Escherichia coli and Staphylococcus aureus in methanol and nhexane extract (Niswa, 2014). Giving Arctium lappa L. root extract 600 and 1,200 mg / kg body weight orally improves function and activity in mice, this is due to the aphrodisiac properties of flavonoids, saponins, lignans and alkaloids (JianFeng et al., 2012).

Medinilla speciosa was still only applied to humans, for no male or female livestock has ever been examined. Male cattle as superior males must have good sperm quality both intellectually and macroscopically. Male cattle have good growth and fertility which would be used for the production of frozen semen (straw) to be used for IB. However, some cattle that were old or almost rejected would experience a decline in the function of the reproductive organs, thus disrupting sperm quality. The injection of prostaglandin hormone (PGF2 $\alpha$ ) was carried out to increase the libido of animals that experience fertility disorders. PGF $2 \alpha$ injection forms the sun's seeds orally in calm lust. Improves hormone synthesis and hormone secretion, litter size and weight at birth (ElKomy and ElSpeiy, 2016). It was suspected that Medinilla speciosa plant extract can produce low livestock libido by regulating the hormone system (testosterone, FSH and LH).

Injection of PGF $2 \alpha$ hormones was a solution to improve fertility, however, the cost factor for purchasing hormones causes breeders not to be able to overcome fertility disorders in their livestock so that the production of superior males would decrease. In the end cattle were sold or cut. So we need cheap and non-toxic herbs.

Medinilla speciosa fruit and leaves could be studied to increase growth, endurance and increase male fertility. Until now no one has found the right dose to be given to male cattle. So does this research. The chemical content as an active substance such as antioxidants, nutrients and amino acids in Medinilla speciosa plants, can help the recovery function. So that this study is expected to determine the content of active compounds in the fruit and leaves of Medinilla speciosa which have potential in male fertility

\section{Materials and Methods}

\section{Method}

Identification of tanin, flavonoids, glycosides and saponins in Parijoto fruit. Testing of tannin content in parijoto fruit was carried out using $\mathrm{FeCl} 3$. The sample was weighed with a digital scale of $0.5 \mathrm{~g}$, then dissolved with $50 \mathrm{~mL}$ of distilled water which had been preheated. The solution was then heated for 15 minutes and filtered using filter paper. Five $\mathrm{mL}$ filtrate was inserted into the test tube and reacted with 2-3 drops of $1 \% \mathrm{FeCl} 3$ solution. If the color of the sample changes to blackish green or dark blue, then the sample contains tannin compounds (Maria et al., 2012 and Ergina et al., 2014).

\section{Identification of Total Flavonoid Compounds}

Identification of flavonoids from ethanol extract 0.5 gram of star fruit, crushed in mortar with a little air, plus a little magnesium metal and 5 drops of $\mathrm{HCl} 2 \mathrm{~N}$, the entire mixture was heated for 5-10 minutes. Then it was filtered hot and the filtrate is left to cool, when alcohol was added, then shaken vigorously, a positive reaction with the formation of red in the layer of alcohol (Jamalan et al., 2016 and Manoi 2009).

\section{Identification of Total saponins Compounds}

Total saponin from ethanol extract of parijotos fruit as much as 0.5 grams in a test tube plus hot and cooled air and then shaken for 10 seconds will produce stable foam for less than 10 minutes as high as $1-10 \mathrm{~cm}$, and by adding 1 drop of foam HCN $2 \mathrm{~N}$ does not disappear which shows the presence of saponins (Mir, 2013). Identification of Glycosides, each 0.5 gram of profit added $5 \mathrm{ml}$ of air, added with glacial acetic acid and 1 drop 
of $\mathrm{FeCl}_{3}$. Then add $1 \mathrm{ml}$ of concentrated sulfuric acid. Creating a brown ring on the surface (Ayoola et al., 2008).

\section{Results and Discussion}

Preliminary research was conducted to determine the types of Parijoto plants taken from Colo Village, Muria Kudus, including Medinilla speciosa species. Determination of type uses determination at the Institute of Technology Bandung.

The results of Qualitative Analysis of Parijoto Fruit and Leaves can be seen in Table 1.

Table 1. Results of Qualitative examination of Secondary Compound Content in Parijoto Fruit and Leaves.

\begin{tabular}{llll}
\hline Compound & $\begin{array}{l}\text { Parijoto } \\
\text { Extract }\end{array}$ & $\begin{array}{c}\text { Fruit } \\
\text { Parijoto Leaves } \\
\text { Extract }\end{array}$ \\
\hline \hline Flavonoids & + & + \\
Saponin & + & + \\
Tanin & + & + \\
Antioxidants & + & + \\
Terpenoid & + & + \\
Beta & + & + \\
carotene & & \\
\hline
\end{tabular}

Based on the above data (Table 1) the content of compounds present in leaves and parijoto fruit are flavonoids, saponins, tannins, terpenoids, beta-carotene and antioxidants. Flavonoids characterized by the formation of red brown in the amyl alcohol layer indicate a positive presence of flavonoids. Test tannins in a positive sample if the results show brownish green or blackish blue. Saponin test could be seen by the appearance or absence of foam.

The results of the compound experiments in Parijoto fruit were based on Table 2. Parijoto fruit has a total of flavonoids and saponins of $3.61 \% \mathrm{~b} / \mathrm{b}$ and $3.71 \% \mathrm{~b} / \mathrm{b}$. Determination of total flavonoid and saponin compounds using UV-vis spectrophotometry method. Every 50 $\mathrm{mg}$ of Parijoto fruit sample contains $3.61 \% \mathrm{~b} / \mathrm{b}$ of total flavonoids. Total saponins were 3. $71 \%$ $\mathrm{b} / \mathrm{b}$ in the content of $50 \mathrm{mg}$ of parijoto fruit samples. The total amount of flavonoids and saponins in the Parijoto fruit indicates the presence of secondary compounds that influence the fertility of livestock

Table 2. Quantitative Test Results of Secondary Compound Content in Parijoto Fruit

\begin{tabular}{llll}
\hline No & Type of compound & $\begin{array}{l}\text { Result } \\
(\% \mathrm{~b} / \mathrm{b})\end{array}$ \\
\hline \hline 1 & $\begin{array}{l}\text { Total Flavonoids Equivalent of } \\
\text { Quercetin }\end{array}$ & 3.61 \\
2 & $\begin{array}{l}\text { Saponin from Quillaja is } \\
\text { Quantitative }\end{array}$ & 3.71 \\
\hline
\end{tabular}

Based on Table 3. total flavonoids and saponins in parijoto leaf samples were $4,91 \%$ $\mathrm{b} / \mathrm{b}$ and $2.65 \% \mathrm{~b} / \mathrm{b} .50 \mathrm{mg}$ of Parijoto leaf samples have $2.65 \% \mathrm{~b} / \mathrm{b}$ of total flavonoids. Total saponin showed $4.91 \% \mathrm{~b} / \mathrm{b}$ indicating that each sample $50 \mathrm{mg}$ produced saponin content of $2.65 \% \mathrm{~b} / \mathrm{b}$. The total number of flavonoids in parijoto fruit is greater (Table 4) than those in parijoto leaves. In contrast to the total saponins in parijoto leaves more were found in parijoto fruit. This indicates that part of the parijoto plant which was in a toxicity test in determining the optimal dosage uses fruit from parijoto.

Table 3. Quantitative Test Results of Secondary Compound Content in Parijoto Leaves

\begin{tabular}{clll}
\hline No & \multicolumn{2}{l}{ Type of compound } & $\begin{array}{l}\text { Result } \\
(\% \mathrm{~b} / \mathrm{b})\end{array}$ \\
\hline \hline 1 & $\begin{array}{l}\text { Total Flavonoids Equivalent of } \\
\text { Quercetin }\end{array}$ & 2.65 \\
2 & $\begin{array}{l}\text { Saponin from Quillaja is } \\
\text { Quantitative }\end{array}$ & & 4.91 \\
\hline
\end{tabular}

The contents of the Parijoto fruit were flavonoids, tannins, saponins and glycosides. The phytochemical screening performed showed that in ethanol extract containing flavonoids, tannins, saponins and glycosides. Parijoto produces flavonoids as an action against microbial infections. Lipophilic flavonoids can also be related to microbial membranes (Nijveldt et al., 2001). Complex compounds can be selected by flavonoids with extracellular proteins and dissolved proteins can also produce complex compounds with bacterial cell walls (Syaima, 2015 dan Sameerah et al., 2013). Flavonoids combined with bacterial DNA which could damage the 
permeability of bacterial cell walls, microsomes, and lysosomes (Umar et al., 2012 and Selawa et al., 2013).

Table 4. Quantitative Test Results for Antioxidant Content (IC50), Total Polyphenols and Tanins in Parijoto Fruit and Leaves

\begin{tabular}{lllll}
\hline No & Sample & $\begin{array}{l}\text { Antioxida } \\
\text { nt Activity } \\
\text { (IC50) } \\
\text { (ppm) }\end{array}$ & $\begin{array}{l}\text { Total } \\
\text { Polyphen } \\
\text { ols } \\
(\%)\end{array}$ & $\begin{array}{l}\text { Tanin } \\
(\%)\end{array}$ \\
\hline \hline 1 & $\begin{array}{l}\text { Parijoto } \\
\text { Leaves }\end{array}$ & 36.84 & 3.95 & 3.52 \\
2 & $\begin{array}{l}\text { Parijoto } \\
\text { Fruit }\end{array}$ & 20.65 & 12.68 & 11.70 \\
\hline
\end{tabular}

The mechanism of saponin as an actibacterial agent by cutting the function of the microbial membrane. Saponins could damage the permeability of cell walls, the prospect of content chords and death through complex hydrogen compounds produced by saponins with cell membranes (Tussanti et al., 2014). Saponins could reduce cell stress and permeability as well as leakage of proteins and enzymes.

The total antioxidants in the fruits and parijoto leaves obtained results of 20.06 and $36.84 \mathrm{ppm}$ respectively (Table 4). This shows in parijoto leaves more antioxidant content compared to parijoto fruit. The activity level of antioxidant activity in the parijoto stem gel preparation was classified as very weak at $>200$ ppm. According to Adewoyin (2017), it is known that it is very strong if the value (IC50 $<50 \mathrm{ppm}$ ), strong (50 ppm <IC50 <100 ppm), moderate (100 ppm <lC50<150 ppm), weak (150 ppm $<$ IC50 $<200 \mathrm{ppm}$ ), and very weak (IC50 <200 $\mathrm{ppm})$. Antioxidants in fruits and flowers as a deterrent to free radicals. According to Wijayanti et al. (2018), antioxidants in plants have the ability to inhibit. Adewoyin et al. (2017) states that free radicals are molecules that have atoms with unpaired electrons, excess free production or reactive oxygen (ROS, reactive oxygen species) could damage sperm, and ROS was one of the causes of infertility. Superoxide anions, hydroxyl radicals and hydrogen peroxide are some of the main ROS found in plasma semen.

Table 4. Produce total polyphenols in parijoto leaves and fruit $3.95 \%$ and $12.68 \%$ respectively. There is a lot of polyphenol content in Parijoto fruit which can be used to counteract free radicals. Polyphenol compounds contained in higher Parijoto fruit compared to Parijoto leaves provide an effective antioxidant effect on lipid oxidation. Polyphenols could protect oxidative stress which could cause free radicals directed at organ damage (Gauthaman et al., 2008). Polyphenols were phenolic derivatived which have antioxidant functions in counteracting free radicals.

Tanin has the ability as an antibacterial that could reverse toxic-causing bacteria. The content of tannin in parijoto leaves and fruit were $3.52 \%$ and $11.70 \%$. Parijoto fruit which contains more tannin compared to Tanin leaves which contain large molecular weight polyphenol compounds consisting of hydroxy and carboxyl groups. Wuluh leaves (Averrhoa bilimbi L.) leaf extract as antibacterial against $S$. aureus and $E$. coli bacteria because they contain tannin compounds (Darsana, 2012). The antimicrobial effects of tannins were also by their ability to activate microbial adhesions, enzymes, cell membrane transport proteins, and mineral absorption. According to Andini (2014), tannins have a function to reduced accumulation in the blood by removing emissions through feces. Levels of flavonoids, tannins and polyphenols which were high in comparable parijoto fruit leaves could provide good impact if used in male fertility treatment.

\section{Conclusions}

In conclusion, the fruit and parijoto leaves have male fertility potential, and the secondary compounds of parijoto fruit were higher compared to parijoto leaves which have the potential to increase male fertility. 


\section{Acknowledgement}

Thank you to Perjuangan University of Tasikmalaya for providing funding for this program through the PDP internal scheme grant program through the Institute for Research and Community Service (LP2M). No. SK: 73/SK/Rek./UP/2018.

\section{References}

Adewoyin M, M Ibrahim, R Roszaman, ML Md Isa, NAM Alewi, AAA Rafa and MNN Anuar. 2017. Male Infertility: The Effect of Natural Antioxidants and Phytocompounds on Seminal Oxidative Stress. Diseases. 5 (9): 1-26.

Andini D. 2014. Potential of katuk leaf (Sauropus androgynus L. Merr) as aphrodisiac. Journal of Majority. 3(7):17-22.

Ayoola GA, HAB Coker, SA Adesegun, AA AdepojuBello, K Obaweya, EC Ezennia and TO Atangbayila.2008. Phytochemical Screening and Antioxidant Activities of Some Selected Medicinal Plants Used for Malaria Therapy in Southwestern Nigeria. Tropical Journal of Pharmaceutical Research. 7(3):1019-1024.

Darsana IGO, INK Besung dan H Mahatmi. 2012. Potensi daun binahong (Anredera cordifolia (tenore) steenis) dalam menghambat pertumbuhan bakteri Escherichia colisecara in vitro. Fakultas Kedokteran Hewan, Universitas Udayana. Indonesia Medicus Veterinus. 1(3): 337 $-351$.

ElKomy AE and ME EL-Speiy. 2016. Polyunsaturated Fatty Acids Combined with Equine Chorionic Gonadotropin to Enhance Reproductive Performance in Aged Rabbit Does. Italia Journal of Animal Science. 14(1).

Ergina, S Nuryanti dan ID Pursitasari. 2014. Uji kualitatif senyawa metabolit sekunder pada daun palado (Agave angustifolia) yang diekstraksi dengan pelarut air dan etanol. Journal Akademik Kimia. 3(3): 165-172

Gauthaman K and AP Ganesan. 2008. The hormonal effects of Tribulus terrestris and its role in the management of male erectile dysfunctionan evaluation using primates, rabbit and rat. Phytomedicine.15 (1-2):44-54.

Hanum AS, E Prihastanti and Jumari. 2017. Ethnobotany of utilization, role, and philosopical meaning of parijoto (Medinilla, spp) on Mount Muria in Kudus Regency, Central Java. The 4th International Conference on Research, Implementation, and Education of Mathematics and Science (4th ICRIEMS) AIP Conf. Proc.
Jamalan M, MA Ghaffari, P Hoseinzadeh, M Hashemitabar and $M$ Zeinali. 2016. Human Sperm Quality and Metal Toxicants: Protective Effects of some Flavonoids on Male Reproductive Function. International of Journal Fertility and Sterility. 10(2): 215-222.

JianFeng C, ZP Ying, X ChengWei, H TaoTao, B YunGui and $C$ KaoShan. 2012. Effect of aqueous extract of Arctium lappa L. (burdock) roots on the sexual behavior of male rats. BMC Complementary and Alternative Medicine. 12(8):1-8.

Leliana N. 2013. Uji Aktivitas Antioksidan serta Penentuan Kandungan Fenolat dan Flavonoid Total dari Buah Parijoto. UIN Syarif Hidayatullah, Jakarta. (Skripsi).

Manoi F. 2009. Binahong (Anredera cordifolia) sebagai obat Penelitian dan Pengembangan Tanaman Industri.Badan Penelitian dan Pengembangan Pertanian. Pusat Penelitian dan Pengembangan Perkebunan, Indonesia. Bulletin Warta. 15(1):4-5.

Maria C, B Erszebet and H Denisa. 2012. Medinilla: an exotic and attractive indoor plant with great value. Journal of Horticulture, Forestry and Biotechnology. 16(2):9-12.

Mir MA. 2013. Qualitative and quantitative analysis of phytochemicals of Taraxacum officinale. Wudpecker Journal of Pharmacy and Pharmocology. 2(1), pp. $001-005$.

Nijveldt RJ, EV Nood, DECV Hoorn, PG Boelens, KV Norren dan PAMV Leeuwen. 2001. Flavonoids: a review of probable mechanisms of action and potential applications. American Journal of Clinical and Nutrition.74:418-425.

Niswah L. 2014. Uji aktivitas antibakteri dari ekstrak buah parijoto (Medinilla speciosa blume) menggunakan metode difusi cakram. Skripsi UIN Syarif Hidayatullah Jakarta. 14-27.

Sameerah AZSA, AJM Al-Fartosya and GF Al-Kanany. 2013. Antibacterial activity of the glycosidic extract from Citrus laurantifoia L. fruits. Der Pharma Chemica. 5(6):73-78.

Selawa W, MRJ Runtuwene dan G Citraningtyas. 2013. Kandungan flavonoid dan kapasitas antioksidan total ekstrak etanol daun binahong [Anredera cordifolia (Ten.) Steenis]. Jurnal IImiah Farmasi. 2(1):18-22.

Syaima. 2015. Isolasi Aktif Antibakteri dari Ekstrak Etil Asetat Buah Parijoto (Medinilla speciosa Blume). Fakultas Kedokteran dan Ilmu Kesehatan. UIN Syarif Hidayatullah, Jakarta. (Skripsi).

Tussanti I and Johan, A. Kisdjamiatun. 2014. Sitotoksisitas in vitro ekstrak etanolik buah parijoto (Medinilla speciosa, reinw.ex bl.) terhadap sel kanker payudara T47D. Jurnal Gizi Indonesia. 2 (3): 56-57. 
Umar A, D Krihariyani dan DT Mutiarawati. 2012. Pengaruh pemberian ekstrak daun binahong (Anredera cordifolia (Ten) Steenis) terhadap kesembuhan luka infeksi Staphylococcus aureus pada mencit. Analis Kesehatan Sains. 1(2):68-75.

Wachida LN. 2013. Uji Aktivitas Antioksidan serta Penentuan Kandungan Fenolat dan Flavonoid
Total dari Buah Parijoto. Skripsi. Program Studi Farmasi UIN, Jakarta.

Wijayanti D, ET Setiatin and E Kurnianto 2018. Leucocyte profile and offspring production of guinea pig (Cavia cobaya) given Anredera cordifolia leaf extract. Journal of Indonesian Tropical Animal Agriculture. 43 (1):19-25. 